Tópico de Interesse Geral

\title{
Importância do exame clínico para o diagnóstico das enfermidades do sistema nervoso em ruminantes e eqüídeos
}

\author{
Franklin Riet-Correa ${ }^{1}$, Gabriela Riet-Correa ${ }^{2}$ e Ana Lucia Schild ${ }^{3}$
}

O EXAME CLínICO correto de um animal com sinais nervosos permite saber a possível localização das lesões no sistema nervoso (SN), o que é fundamental para o diagnóstico presuntivo e tratamento. Permite, também, recomendar o sacrifício de animais sem possibilidades de tratamento. Para o estudo das enfermidades do SN é necessário um intercâmbio permanente entre o clínico e o patologista. Isto significa que o clínico deve incorporar a sua rotina a realização sistemática de necropsias e o envio dos materiais mais adequados para o diagnóstico no laboratório. Como nas enfermidades do SN a letalidade é alta, essa deve ser uma prática freqüiente, imprescindível, tanto para o clínico como para o patologista. Em uma necropsia correta do SN é necessário retirar o encéfalo inteiro (cérebro, cerebelo e tronco encefálico). Quando se suspeita de uma enfermidade infecciosa o encéfalo deve ser cortado longitudinalmente. Uma metade deve ser fixada em formol a $10 \%$ (ou até $20-30 \%$ para fixação mais rápida e eficiente) em um volume aproximado de uma parte de tecido em 10 partes de formol. A outra metade deve ser enviada refrigerada para exame microbiológico. Apesar das dificuldades, a campo, de retirar a medula nos grandes animais, isto é necessário quando o animal apresenta sinais clínicos que sugerem uma lesão medular ou uma lesão difusa do SN.

Antes de realizar o exame do SN é necessário conhecer os dados epidemiológicos e a história clínica do caso com a maior precisão possível. Conhecer a evolução clínica do animal é importante: cistos, tumores e abscessos podem ter evolução lenta; enfermidades infecciosas, que causam inflamação difusa do $\mathrm{SN}$, e traumatismos tem evolução rápida. $\mathrm{O}$ conhecimento das diferentes enfermidades que afetam o sistema nervoso dos ruminantes na região onde o clínico trabalha é, também, muito importante.

Para o exame clínico correto do SN é necessário ter conhecimento prévio de alguns aspectos anatômicos e fisioló-

\footnotetext{
${ }^{1}$ Centro de Saúde e Tecnologia Rural, Universidade Federal de Campina Grande, Campus de Patos, Jatobá, Patos, PB 58700-000. E-mail: riet@cstr.ufpb.br;

${ }^{2}$ Depto de Patologia, Faculdade de Veterinária, Universidade Federal de Goiás, Jataí, GO.

${ }^{3}$ Laboratório Regional de Diagnóstico, Faculdade de Veterinária, Universidade Federal de Pelotas, Pelotas, RS 96010-900.
}

gicos do mesmo. No sistema nervoso central, os neurônios encontram-se na substância cinzenta. Esta está localizada na periferia do cérebro e cerebelo, no centro da medula, e distribuída em núcleos no tronco encefálico. A substância branca é formada por axônios mielinizados que se distribuem em tratos. Estes tratos podem ser eferentes (motores) ou aferentes (sensitivos); estes últimos transmitem informação referente a dor, temperatura, propriocepção, tato, sabor, etc. Alguns desses tratos transmitem, também, informações referentes ao sistema nervoso autônomo. Os tratos são denominados segundo seu local de origem e terminação (espinhocerebelares, vestibuloespinhais, etc.)

Mediante o exame do sistema nervoso podem ser detectadas alterações basicamente em 4 funções: 1) motora; 2) proprioceptiva; 3) sensitiva; 4) do sistema nervoso autônomo.

A função motora é realizada por dois tipos de neurônios: os neurônios motores superiores, localizados principalmente no tronco encefálico, em grandes animais, e que têm uma função inibidora sobre os neurônios motores inferiores; e os neurônios motores inferiores, localizados nos cornos ventrais da medula. Uma alteração motora manifesta-se clinicamente por paralisia, que pode ser total ou parcial (paresia). A paresia, dependendo da localização da lesão, aparece como uma debilidade dos músculos dos membros, cabeça e/ou pescoço. Quando as lesões localizam-se nos neurônios motores inferiores a paralisia é flácida. Quando a lesão afeta os neurônios motores superiores ou os tratos que conduzem seus axônios a paralisia é espástica; isto porque os neurônios motores inferiores são liberados da função inibidora exercida normalmente pelos neurônios motores superiores. Em ruminantes e equiinos as lesões no córtex cerebral não causam paralisia, uma vez que os neurônios motores superiores localizam-se principalmente no tronco encefálico. $O$ contrário ocorre com os primatas, que possuem neurônios motores superiores no córtex cerebral.

A função proprioceptiva permite ao animal ter noção espacial da localização de seus membros, pescoço e cabeça. Esta noção é transmitida desde receptores localizados principalmente nas articulações através dos tratos espinhocerebelar, espinhoreticular e espinhotalâmico a neurônios localizados no tronco encefálico e cerebelo. Lesões localizadas nesses tratos ou neurônios causam deficiências propriocep- 
tivas, conhecidas como ataxia. Algumas provas mencionadas mais adiante servem para determinar deficiências proprioceptivas.

Além da informação proprioceptiva os neurônios sensitivos do sistema nervoso periférico transmitem informações de sensações dolorosas para os neurônios sensitivos da medula, tronco encefálico e cerebelo e estas a enviam ao cérebro para um processamento posterior da informação. As deficiências nocioceptivas são detectadas observando a resposta a estímulos dolorosos (pinçamento com agulhas, por exemplo), mas sempre deve-se levar em consideração que o animal pode não responder por deficiência nocioceptiva, ou por incapacidade para responder devido a paralisia. Nos casos de paralisia é importante observar a expressão facial do animal para detectar sinais de dor.

O sistema nervoso autônomo (simpático e parassimpático) controla a atividade da musculatura lisa e cardíaca e das glândulas. Forma parte dos nervos oculomotor, facial, vago e glossofaríngeo e, também, encontra-se na medula espinhal. Lesões nos nervos cranianos mencionados anteriormente podem causar anormalidades na contração das pupilas, na salivação e na atividade da musculatura lisa do sistema digestivo e respiratório superior. Alterações do sistema nervoso autônomo relacionadas à medula espinhal causam alterações funcionais das vísceras das cavidades torácica e abdominal. Lesões no vago devido a reticulite traumática causam diminuição dos movimentos dos pré-estômagos (indigestão vagal). Defeitos no controle dos esfíncteres e motilidade da bexiga e reto são causados por alterações do sistema parassimpático localizado na região sacra da medula espinhal.

Lesões no hipotálamo podem causar distúrbios na regulação da temperatura (hipertermia ou hipotermia).

\section{LOCALIZAÇÃO DAS LESÕES E SINAIS CLÍNICOS}

Lesões localizadas no cérebro e tálamo causam alterações da atitude ou do estado mental: agressividade, depressão, sonolência, mania, galope desenfreado, andar compulsivo, pressão da cabeça contra objetos, torneio, bocejos, mugidos, convulsões (contrações musculares involuntárias com perda do conhecimento) e coma. Nas lesões focais unilaterais o animal pode apresentar desvio lateral da cabeça e pescoço. Em alguns casos em que a lesão afeta o cérebro causando edema cerebral (polioencefalomalacia, abscesso cerebral) observa-se opistótono. Este sinal, que ocorre, também, nas afecções cerebelares, deve-se ao aumento do tamanho do cérebro que empurra o cerebelo através do foramen magno causando a herniação do mesmo.

A cegueira quando é de origem central é causada por uma lesão na região occipital do córtex cerebral. Na cegueira de origem central há ausência de lesões nos olhos e presença de reflexo pupilar. Cegueira sem resposta ao estímulo da luz na pupila é causada por lesões da retina, nervo óptico, quiasma óptico ou trato óptico rostral. Ausência do reflexo pupilar, sem cegueira, indica lesão do nervo oculomotor.

Lesões localizadas no cerebelo causam ataxia, dismetria (principalmente hipermetria) e tremores de intenção. Os tremores de intenção, principalmente em humanos, ocorrem em consequiência de uma ação voluntária; em animais a forma mais fácil de identificar tremores de intenção é através da observação de movimentos rítmicos laterais da cabeça, que aumentam quando o animal é estimulado a realizar alguma atividade. $O$ animal com lesões cerebelares permanece com os membros abertos, cambaleia e tende a cair.

Lesões localizadas no tronco encefálico causam depressão, paresia e, principalmente, sinais de alterações dos nervos cranianos (ver exame da função dos nervos cranianos). Quando há torneio, com alterações da marcha, a lesão pode estar localizada na medula oblonga.

Quando a lesão localiza-se no sistema vestibular (ouvido interno, nervo vestíbulo-coclear e núcleos vestibulares) observam-se ataxia, torção da cabeça (em seu eixo longitudinal), nistagmo e estrabismo. $O$ animal não mantém o equilíbrio e pode girar sobre seu corpo ou de lado. Se a lesão é unilateral $\mathrm{o}$ animal cai ou gira para o lado afetado. $O$ sistema vestibular é um sistema proprioceptivo, que ajuda o animal a manter sua orientação e posicionamento no ambiente em que está. Ajuda a manter a posição e coordenar os movimentos da cabeça, tronco e membros e a manter o equilíbrio durante a marcha e o descanso. Os núcleos dos nervos cranianos III, IV e VI, que controlam os movimentos dos olhos, estão em contato com o sistema vestibular.

As lesões na medula espinhal causam diversos graus de debilidade, ataxia, alterações nocioceptivas e do sistema nervoso autônomo. A presença e gravidade dos sinais clínicos depende de dois fatores: o segmento da medula em que está localizada a lesão; e a extensão e profundidade da mesma, que determinam os tratos que foram afetados (motores, proprioceptivos ou sensitivos) e se está afetada, também, a substância cinzenta, considerando que quando estão afetados os cornos dorsais as alterações são sensitivas ou proprioceptivas e quando estão afetados os cornos ventrais as alterações são motoras. Alguns critérios para determinar a localização das lesões medulares são mencionados a seguir:

1) Paralisia dos neurônios motores superiores (NMS) causa paralisia espástica, aumento do tono muscular e dos reflexos;

2) Paralisia dos neurônios motores inferiores (NMI) causa paralisia flácida, com diminuição dos reflexos e do tono muscular e atrofia muscular neurogênica rápida;

3) Uma lesão moderada na medula cervical pode causar sinais de ataxia somente nos membros pélvicos;

4) Em um animal sem sinais eurológicos da cabeça a lesão pode estar localizada em qualquer região da medula;

5) É difícil diferenciar entre ataxia e debilidade, mas não é importante uma vez que os tratos ascendentes proprioceptivos e os tratos motores descendentes estão juntos na substância branca da medula;

6) Com lesões compressivas locais na medula cervical ou tronco encefálico os sinais neurológicos são mais severos nos membros pélvicos do que nos torácicos;

7) Quando o animal está em decúbito lateral e não consegue levantar a cabeça, a lesão pode estar localizada nos tratos descendentes do tronco encefálico ou na medula cervical provavelmente entre C1 e C4. Lesões unilaterais impedem que o animal levante a cabeça quando a lesão está do lado superior. Um animal com lesão 
entre a C4 e T2 pode levantar a cabeça, mas permanece em decúbito e tanto os membros posteriores quanto os anteriores apresentam paralisia espástica. Uma lesão completa, antes da T2 resulta em morte por asfixia devida a paralisia do nervo frênico.

8) Alterações nos membros pélvicos, sem alterações nos torácicos, indicam lesão tóraco-lombar. Em caso de lesões severas nesta região o animal pode adotar a posição de cão sentado. Se não consegue adotar esta posição é possível que a lesão esteja localizada cranial à $\mathrm{T} 2$;

9) Lesões localizadas na intumescência torácica (C6-T2) causam severas alterações nos membros torácicos e pélvicos. Nesta região lesões somente de NMI afetam exclusivamente os membros torácicos e não os pélvicos;

10) Lesões da região sacra causam incontinência urinária e retenção de material fecal. Não causam paralisia ou ataxia dos membros pélvicos;

11) A síndrome de Schiff-Sherrington ocorre nas lesões compressivas graves da região tóraco-lombar, que causa paralisia de NMI nos membros pélvicos e de NMS nos membros torácicos. Isto porque neurônios localizados entre L1 e L7 são responsáveis pela inibição de alguns neurônios motores da intumescência torácica;

12) Uma lesão leve da medula afeta os tratos espinhocerebelares e vestíbulo espinhais (NMS) que estão localizados superficialmente, causando debilidade extensora (NMS) e ataxia;

13) Em lesões bilaterais graves ocorre perda de nociocepção do periósteo dos dedos e da cauda;

14) As provas dos reflexos espinhais são úteis para localizar lesões em áreas específicas. Em um reflexo monossináptico (reflexo patelar por exemplo) participa um neurônio sensitivo, um neurônio motor inferior, o nervo aferente e o eferente. A ausência de reflexo indica uma lesão em alguma dessas estruturas. Se está alterada somente a porção motora o animal não tem reflexo mas sente dor.

15) Lesões dos plexos lombossacro e braquial causam paralisia ou paresia dos membros pélvicos ou torácicos com redução ou ausência dos reflexos e da sensibilidade;

16) As provas de sensibilidade para detectar hiperestesia, parestesia ou anestesia, utilizando agulhas, por exemplo, podem servir para localizar lesões da medula espinhal. Entretanto, devemos considerar que as reações à dor variam entre animais e, em um mesmo animal, entre as diferentes regiões.

\section{Exame da cabeça}

Observar se existem sinais característicos de lesões do cérebro e tálamo, cerebelo, tronco encefálico ou sistema vestibular (ver páginas anteriores).

\section{Exame dos nervos cranianos}

Algumas das provas a serem realizadas para detectar alterações dos nervos cranianos e os sinais clínicos mais freqüentes são mencionados a seguir.

I. Olfatório. Testar resposta a químicos não irritantes (xilol, benzeno) e busca de alimentos.

II. Óptico. Realizar o exame da visão ameaçando com a mão. Ver capacidade de desviar obstáculos e constatar o reflexo pupilar com uma fonte de luz. As duas pupilas devem contrair-se simultaneamente. Na cegueira causada por lesão do córtex occipital não há perda do reflexo pupilar. Neste caso a lesão é contralateral (lesões do encéfalo direito causam cegueira do olho esquerdo)

III. Oculomotor. $\mathrm{O}$ animal vê, mas não apresenta reflexo pupilar. Em lesões unilaterais contrai-se somente uma pupila. Pode haver estrabismo ventro-lateral e/ou paralisia da pálpebra (ptose).

IV. Troclear. Observa-se estrabismo dorsal.

V. Trigêmeo. Avaliar o tono da mandíbula e os movimentos mastigatórios. Ocorre paralisia da mandíbula. Ver se há atrofia dos músculos masseter ou temporal. Ver reflexo palpebral. Examinar perda de sensibilidade da face, córnea e mucosa nasal.

VI. Abducente. Observam-se estrabismo medial e falta de retração do globo ocular ou exoftalmia.

VII. Facial. Causa paralisia da face (pálpebra, orelha, lábio, nariz).

VIII. Vestíbulo coclear. Há surdez e desequilíbrio para o lado da lesão (unilateral) ou para os dois lados (bilateral). Observa-se torção da cabeça e/ou nistagmo horizontal ou rotatório.

IX e X. Glossofaríngeo e vago. O glossofaríngeo é sensitivo e o vago é motor para a laringe e faringe. Suas alterações causam disfagia, megaesôfago, paralisia ou paresia da faringe e alterações da voz. Examinar o reflexo de deglutição.

XI. Acessório. Observa-se atrofia dos músculos esterno cefálico, braquiocefálico e trapézio.

XII. Hipoglosso. Observar controle muscular da língua, assim como desvio ou atrofia da mesma.

\section{Exame da postura e marcha (alterações do tronco encefá- lico, cerebelo o medula)}

Animais com lesões do córtex cerebral e tálamo apresentam marcha normal. Lesões do tronco encefálico causam ataxia, paresia ou paralisia dos membros. Lesões do cerebelo causam ataxia ou dismetria. Se nenhuma anormalidade é encontrada no exame da cabeça é provável que a lesão esteja localizada na medula ou nos nervos periféricos.

As principais alterações a serem detectadas durante a marcha são ataxia (propioceptiva) e debilidade (motora). Sinais de ataxia ou debilidade podem ser detectados puxando a cauda ou empurrando o animal para um lado durante a marcha; observa-se que o animal não apresenta ou apresenta menor resistência que o normal a esta ação. A debilidade é mais marcada em casos de paralisia dos neurônios motores inferiores. Quando há paralisia dos neurônios motores superiores os membros estão rígidos e o animal, aparentemente está mais forte. A debilidade nota-se, também, quando o animal, caminhando ou em estação, afrouxa os membros. Quando caminha em círculos ou com a cabeça levantada pode cair ou dobrar os membros. Quando um dos membros é suspenso, o membro oposto pode apresentar dificuldade para sustentar o peso do corpo, apresentando tremores ou causando desequilíbrio ou queda. Ataxia é um defeito proprioceptivo inconsciente que se evidencia como incoordenação durante a marcha. Pode causar cambaleio do corpo ou abdução exagerada dos membros ao caminhar ou correr. Durante a estação o animal pode permanecer com os membros cruzados. A ataxia pode ser detectada colocando o membro para fora ou para dentro do seu eixo 
normal e observando se o animal retorna o mesmo a sua posição original. Pode, também, se flexionar o membro deixandoo apoiado nas pinças e constatando seu retorno à posição normal. Detecta-se, ainda, fazendo o animal caminhar passando por obstáculos de alguns centímetros de altura: se há deficiência proprioceptiva o animal tende a bater nos objetos com a parte anterior dos cascos.

Deve se considerar que as lesões musculares ou neuromusculares podem causar, também, alterações na postura e marcha. Debilidade severa nos 4 membros, sem ataxia, espasticidade ou outras alterações evidentes do SN, sugere enfermidade neuromuscular. Debilidade em um só membro é sugestiva de uma lesão do nervo periférico ou uma lesão muscular desse membro.

\section{Exame do pescoco e membros anteriores}

Ver sensibilidade da pele. Ver posicionamento proprioceptivo mediante a adução ou abdução dos membros, observando se $o$ animal os recoloca em posição normal. 0 reflexo da colocação tátil pode ser examinado vendando os olhos do animal e fazendo-o andar para observar a colocação correta dos membros. O cruzamento dos membros pode indicar a perda do sentido proprioceptivo. Ver se o animal consegue corrigir sua posição depois de colocado em decúbito lateral. Ver lesões em C6-T2 ou no plexo braquial mediante o reflexo flexor ou de retração comprimindo a pele ou os dedos e observando a flexão do membro. Examinar a sensibilidade (nociocepção) da região. A dor significa que o nervo sensitivo periférico, a medula e as vias do tronco encefálico para o córtex estão normais. Ver se há atrofia dos músculos dos membros e do pescoço.

Se não existem alterações no exame da cabeça e os membros torácicos estão alterados, a lesão está localizada no plexo braquial ou medula. Em lesões da medula cervical os membros anteriores estarão alterados e os reflexos dos membros posteriores estarão normais ou exagerados. Se não há alterações da cabeça ou membros anteriores a lesão estará localizada atrás da $\mathrm{T} 2$.

\section{Exame do tronco, membros posteriores, ânus e cauda}

O tronco é observado quando há postura anormal, desvios de coluna, dor, insensibilidade ou hiperestesia a picadas suaves de agulhas e atrofia muscular. Constatar posicionamento proprioceptivo dos membros posteriores (da mesma forma que nos anteriores). Ver reflexo do panículo pela contração do músculo cutâneo na resposta a picadas de agulha. Do mesmo modo ver contração do esfíncter anal e da cauda. Ver reflexo patelar e reflexo flexor.

Para escrever o texto anterior foram consultados de Lahunta (1983), Mayew (1989), King (1994), Summers et al. (1995), Radostits et al. (2000) e Merk Manual (2001).

\section{SINAIS CLÍNICOS E LOCALIZAÇÃO DAS LESÕES EM ALGUMAS ENFERMIDADES DO SN DE RUMINANTES NO BRASIL E URUGUAI}

\section{Hidrocefalia}

É uma enfermidade congênita caracterizada por dilatação com presença de líquido nos ventrículos. $\mathrm{O}$ animal apre- senta depressão, sonolência, mugidos contínuos, falta de relação com o ambiente e, ocasionalmente, não se mantêm em estação. Há aumento de volume do cérebro e do crânio.

\section{Hipoplasia cerebelar}

Observa-se hipermetria e perda de equilíbrio. Os sinais aparecem ao nascimento e são estáveis. O cerebelo está diminuído de tamanho. Freqüientemente é causada pela infecção do feto pelo vírus da diarréia viral bovina.

\section{Abiotrofia cerebelar}

Observam-se hipermetria, perda de equilíbrio e ataques epileptiformes. Pode aparecer ao nascimento ou alguns dias depois. Os sinais são progressivos e levam à morte. Há lesões histológicas de degeneração das células de Purkinje do cerebelo.

\section{Hipermetria hereditária}

Enfermidade não progressiva observada na raça Shorthorn, causada por gene recessivo autossômico e caracterizada por sinais clínicos de hipermetria. Não são observadas lesões macroscópicas nem histológicas.

\section{Carência de cobre}

Afeta bovinos no Rio Grande do Sul e ovinos e caprinos na região Nordeste do Brasil. Aparece ao nascimento ou algumas semanas depois. Causa ataxia e debilidade progressivas, que levam a uma paralisia flácida. Podem observar-se tremores musculares, principalmente da cabeça. Alguns animais nascem com paralisia. Observam-se degeneração neuronal, hipomielinogênese e lesões degenerativas (degeneração Walleriana) da mielina, principalmente na medula.

\section{Polioencefalomalacia}

Causa lesões degenerativas da córtex cerebral. Os sinais mais evidentes são cegueira, opistótono, nistagmo, estrabismo, incoordenação e depressão. Pode ocorrer devido a carência de tiamina, intoxicação por enxofre ou intoxicação por sal. Microscopicamente, podem observar-se lesões degenera-tivas no córtex cerebral. Há edema cerebral evidenciado pela herniação do cérebro por debaixo do tentório e do cerebelo através do forame magno. Alguns dos sinais clínicos são causados pelo edema cerebral, que comprime o cerebelo e o tronco encefálico. Histologicamente, observa-se degeneração e necrose do córtex cerebral. Em casos iniciais há resposta ao tratamento com vitamina $\mathrm{B}_{1}$.

\section{Intoxicação por chumbo}

A localização das lesões e os sinais clínicos cerebrais são similares aos da polioencefalomalacia. $\mathrm{O}$ edema cerebral é menos marcado que nesta última.

\section{Encefalite por herpes vírus bovino-5}

Esta infecção causa, também, polioencefalomalacia, portanto os sinais clínicos são semelhantes as anteriores, podendo ser mais graves devido à encefalite difusa do cérebro e tronco encefálico. 


\section{Mieloencefalite por herpesvírus-eqüino-1}

O herpesvírus eqüino- 1 causa aborto, doença neonatal e, eventualmente, sinais clínicos neurológicos que podem ocorrer isolados ou junto com as outras formas da infecção. Geralmente afeta eqüinos adultos que apresentam andar cambaleante, debilidade e incoordenação, que iniciam nos membros posteriores, atinge os anteriores e leva ao decúbito. Podem ocorrer retenção de urina e fezes e ereção. Sinais dos nervos craneanos são menos frequentes. As lesões se localizam preferentemente nos vasos sangüíneos da substância branca da medula com marcada infiltração perivascular de células mononucleares e áreas de malacia.

\section{Encefalomielites virais dos eqüinos}

As encefalomielites virais dos eqüinos são enfermidades infecciosas produzidas por 3 tipos diferentes, mas relacionados, de Alphavirus: Leste (EEE), Oeste (WEE) e Venezuela (VEE), transmitidos por mosquitos. As manifestações clínicas são variáveis e podem ser inaparentes. Os sinais neurológicos incluem ranger de dentes, depressão, ataxia, andar em círculos ou a esmo, pressão da cabeça contra objetos, hiperexcitabilidade, paralisia, anorexia, cegueira e, na fase final, embotamento dos sentidos. Os cavalos mantém a cabeça baixa, orelhas caídas, ptose labial e protusão da língua. Há também, paralisia da faringe e, em decúbito, movimentos de pedalagem. Não se observam lesões macroscópicas e as lesões histológicas estão limitadas à substância cinzenta. Há necrose neuronal e neuroniofagia, manguitos perivasculares com presença de células mono e polimorfonucleares e microgliose. As lesões são mais acentuadas no córtex cerebral, tálamo e hipotálamo.

\section{Raiva}

A raiva paralítica, transmitida por morcegos hematófagos, causa ataxia e debilidade dos membros. Os sinais são progressivos, iniciando-se nos membros posteriores, estendendo-se posteriormente aos anteriores e finalizando em decúbito permanente. Pode haver tenesmo retal e relaxamento do esfíncter anal. Há sinais de alterações do tronco encefálico, como paralisia da língua. Na raiva urbana, transmitida por cães pode haver sinais de alteração do córtex cerebral, como mania, agressividade e mugidos. Não há lesões macroscópicas e as lesões histológicas na raiva paralítica localizam-se principalmente no tronco encefálico e medula. Há corpúsculos de inclusão principalmente no cerebelo. Em eqüinos as manifestações da enfermidade são variáveis, podendo ocorrer paralisia ascendente, hiper-salivação, ataxia e paresia dos membros posteriores, paralisia da laringe, cólica e perda do tônus do esfincter anal.

\section{Febre catarral maligna}

Afeta bovinos e cervos. Quando apresenta sinais nervosos causa depressão profunda, incoordenação, pressão da cabeça contra objetos, convulsões e paralisia. Causa também, ceratite, ulcerações dos sistemas digestivo e respiratório com salivação e corrimento nasal e febre. Causa uma vasculite difusa no $\mathrm{SN}$ e outros órgãos. Está associada à presença de ovinos junto com os bovinos. Apresenta, geralmente, baixa morbidade e letalidade de praticamente $100 \%$.

\section{Leucose}

Em bovinos uma das formas clínicas mais frequiente do linfossarcoma é a nervosa. Caracteriza-se por debilidade e ataxia progressiva dos membros posteriores e afeta animais adultos. Em semanas ou meses o quadro evolui para decúbito esternal permanente e $o$ animal tem que ser sacrificado. $O$ tumor localiza-se nas meninges da região sacra e última porção lombar da medula causando compressão. A enfermidade tem sido observada, também, em caprinos com lesões localizadas na região torácica da medula.

\section{Encefalite e artrite caprina (CAE)}

É um lentivirus da família Retroviridae, difundido no Brasil, que causa artrite, pneumonia, mastite e encefalite em caprinos. A forma nervosa afeta principalmente cabritos de 2 a 4 semanas de idade. Os sinais clínicos caracterizam-se, principalmente, por paralisia dos neurônios motores superiores e deficiências proprioceptivas. Em alguns dias pode evoluir para paralisia dos 4 membros e decúbito permanente. Microscopicamente observam-se múltiplos focos de infiltrados perivasculares de linfócitos e macrófagos na substância branca cerebral, associados a desmielinização, e infiltração de células inflamatórias mononucleares na substância cinzentas da medula espinhal. Pode haver lesões na parte caudal do tronco encefálico.

\section{Visna}

Afeta ovinos e é causada por um lentivirus da família Retroviridae semelhante ao da CAE. Apresenta-se com uma forma nervosa (visna) ou uma forma respiratória (maedi). No Brasil têm sido detectados anticorpos para este vírus e o mesmo foi isolado de um cordeiro sem sinais clínicos e de uma ovelha com artrite, perda progressiva de peso e mastite. A forma nervosa afeta ovinos adultos causando paresia e ataxia gradual dos membros posteriores, que progride lentamente para paralisia. Podem-se observar, também, postura anormal da cabeça, nistagmo e tremores dos lábios. As lesões são similares às descritas para CAE.

\section{Scrapie}

É uma encefalopatia espongiforme causada por um príon, que tem sido diagnosticada diversas vezes no Brasil. Os sinais clínicos são lentamente progressivos e, inicialmente, $o$ animal pode andar separado do rebanho. $O$ sinal clínico característico é o prurido, que faz que o ovino se coce contra objetos causando perda de lã e lesões da pele. Podem observar-se ataxia e hipermetria, assim como ranger de dentes. As lesões histológicas, localizadas principalmente no mesencéfalo, ponte, medula oblonga e medula espinhal, caracterizamse por vacuolização de neurônios e do neurópilo.

\section{Listeriose}

Afeta esporadicamente bovinos, ovinos, caprinos e bubalinos. Causa paralisia assimétrica dos nervos cranianos, principalmente o facial. Os sinais mais freqüentes são paralisia unilateral da orelha, pálpebra e lábio. Outros sinais de alterações de outros nervos cranianos podem ocorrer, inclusive sinais do sistema vestibular. As lesões localizam-se no 
tronco encefálico e na maioria das vezes são somente histológicas, com presença de microabscessos.

\begin{abstract}
Abscessos do SN
Os sinais clínicos dependem da localização do abscesso. Uma localização frequiente é nas vértebras dorsais e lombares. Ocorrem em consequiência de infecções umbilicais. Podem ocorrer, também, mielite ascendente em ovinos depois do corte da cauda. Os sinais são em geral progressivos, levando finalmente a paralisia dos membros posteriores. Podem ocorrer abscessos da hipófise em bovinos que foram submetidos ao desmame interrompido para diminuir o anestro pós-parto das vacas. Nestes casos há evidências de compressão do nervo trigêmeo e abducente. Infecções bacterianas que chegam ao tronco encefálico através do nervo vestíbulo-coclear são observados como complicação da otite parasitária causada por Raillietia auris e nematódeos da família Rhabditidae. Nestes casos observa-se uma síndrome vestibular. Podem haver lesões em outras áreas do tronco encefálico causando sinais associados a outros nervos cranianos.
\end{abstract}

\section{Botulismo}

O botulismo causa paralisia flácida generalizada, afetando também a língua, cauda e mandíbula. Inicialmente observa-se dificuldade para a marcha seguida de decúbito permanente (síndrome da vaca caída). Não apresenta lesões macroscópicas nem histológicas.

\section{Tétano}

Surtos de tétano são observados freqüentemente em bovinos, ovinos e caprinos, associados a traumatismos coletivos: tosquia, banhos, castração, corte de cauda e vacinações ou administração de medicamentos com produtos ou seringas contaminadas. Os eqüinos são mais sensíveis que os ruminantes. O diagnóstico realiza-se pelos dados epidemiológicos e sinais clínicos que são característicos: tetania e rigidez generalizada da musculatura, trismo mandibular, prolapso da terceira pálpebra, rigidez da cauda, orelhas eretas, hiperexcitabilidade, tetania dos músculos masseteres, constipação e retenção urinária. Não causa lesões no SN.

\section{Necrose simétrica focal}

É uma enfermidade de curso subagudo ou crônica causada pela toxina épsilon do Clostridium perfringens tipo D. Ocorre, preferentemente, em cordeiros, na primavera. Os sinais clínicos são depressão, marcha sem rumo ou em linha reta, incoordenação e, ocasionalmente, cegueira. A maioria dos animais morrem em 1 a 14 dias. Macroscopicamente, observam-se áreas marrons ou avermelhadas, simétricas, focais, localizadas na cápsula interna, núcleos da base, tálamo, mesencéfalo e pedúnculos cerebelares. Histologicamente, observam-se degeneração e necrose nessas áreas.

\section{Meningite bacteriana}

É frequiente em bovinos no período neonatal. Está associada a imunodepressão, que pode ser causada pela ingestão inadequada de colostro ou pela infecção pelo vírus da diar- réia viral bovina ou outros agentes. Os sinais clínicos caracterizam-se por febre, depressão ou hiperestesia, opistótono com a musculatura do pescoço rígida de forma que a tentativa de flexão do mesmo é difícil, reflexos aumentados e, ocasionalmente, convulsões em resposta a estímulos auditivos. Na necropsia pode observar-se inflamação purulenta a fibrinopurulenta das leptomeninges, que estão de aspecto opaco ou floculento. A meningite pode estar associada a processos inflamatórios em outros órgãos.

\section{Cenurose}

Afeta ovinos e com menor freqüência bovinos. Os sinais clínicos, que em geral são progressivos, dependem da localização do cisto. A localização mais freqüente é no cérebro, causando movimentos de torneio, cegueira e depressão. É frequiente, também, a localização em cerebelo causando hipermetria, incoordenação, desequilíbrio e outros sinais característicos desta localização. Ocorrem com menor freqüência na medula, com sinais progressivos de ataxia e debilidade. Algumas vezes os sinais são estáveis em conseqüência da morte e degeneração do parasita no SN.

\section{Encefalopatia hepática (intoxicações por Senecio spp, Crotalaria spp e Echium plantagineum)}

Nestas intoxicações em bovinos observam-se agressividade, algumas vezes incoordenação, tenesmo retal e, ocasionalmente, prolapso retal e diarréia. Os sinais do sistema nervoso são causados, principalmente, pela espongiose (vacuolização) da substância branca do cérebro e cápsula interna, que ocorrem em consequiência da insuficiência hepática (hiperamonemia). Não se sabe qual é a causa do tenesmo retal que, junto com a agressividade, é um dos sinais mais característicos. Em eqüinos podem ocorrer emagrecimento, depressão ou hiperexcitabilidade, andar a esmo, pressão da cabeça contra objetos, torneio ou galope desenfreado. As lesões histológicas do cérebro caracterizam-se pela presença de grupos de astrócitos de Alzheimer tipo II no cortex e gânglios da base. Tanto em equídeos quanto em bovinos há lesões hepáticas de fibrose, megalocitose e proliferação de células dos ductos biliares.

\section{Intoxicação por Ateleia glazioviana}

Esta intoxicação, que causa, também, abortos e fibrose cardíaca em bovinos pode causar sinais nervosos caracterizados por letargia, depressão, cegueira e andar lento e cambaleante. Os animais permanecem por longos períodos dentro de sangas ou banhados e em decúbito freqüente, algumas vezes com a mandíbula apoiada no solo. Não há lesões macroscópicas no SN. Histologicamente, observa-se vacuolização da substância branca (espongiose), principalmente da medula cerebelar, pedúnculos cerebelares e tronco encefálico.

\section{Intoxicações por Claviceps paspali, Cynodon dactylon, Ipomoea asarifolia e Phalaris spp}

Estas intoxicações causam uma síndrome tremorgênica, que se caracteriza por tremores e incoordenação. Inicialmente os tremores podem afetar a cabeça e o pescoço, mas quando 
os animais são agitados agravam-se afetando todo o corpo e provocando a queda dos animais, que, posteriormente, levantam-se em alguns minutos. Quando se retira a fonte de intoxicação os animais se recuperam em 7-15 dias. As intoxicações por $C$. paspali e $C$. dactylon, que afetam bovinos no sul do Brasil, não causam lesões macroscópicas ou histológicas de significado. A intoxicação por I. asarifolia afeta caprinos, ovinos e bovinos no Nordeste do Brasil e também não causam lesões histológicas. A intoxicação por Phalaris spp., que pode causar, também, outros sinais nervosos e morte súbita, afeta bovinos em Santa Catarina e pode afetar ovinos. Causa lesões macroscópicas caracterizadas pela presença de um pigmento verde-azulado principalmente no tálamo, medula oblonga e mesencéfalo. Esse pigmento observa-se microscopicamente dentro dos neurônios (Loretti et al. 2003).

\section{Intoxicação por resíduos de cevada contaminados com Aspergillus clavatus}

No Rio Grande do Sul a intoxicação por toxinas de Aspergillus clavatus foi recentemente diagnosticada em bovinos leiteiros alimentados com resíduos de cevada. Os animais apresentam paralisia flácida e alterações da marcha caracterizadas por incoordenação motora, fraqueza, paresia e paralisia dos membros posteriores. Quando movimentados ou excitados, apresentam tremores musculares e freqüentemente caiam. A morte ocorre após um curso clínico de 2 a 14 dias. Na necropsia observam-se lesões degenerativas e necróticas dos músculos dos membros anteriores e posteriores. Histologicamente há degeneração e necrose neuronal no tronco encefálico, medula oblonga, ponte e cornos ventrais da medula espinhal.

\section{Intoxicação por Solanum fastigiatum e $S$. paniculatum}

Esta intoxicação afeta bovinos e caracteriza-se por crises epileptiformes periódicas. Quando os animais são perturbados apresentam tremores, opistótono, nistagmo, extensão dos membros anteriores, desequilíbrio e quedas para trás ou para o lado. Recuperam-se rapidamente em alguns segundos até um minuto. Entre as crises não apresentam sinais clínicos significativos. Não há lesões macroscópicas e as lesões histológicas caracterizam-se por vacuolização e posterior desaparecimento das células de Purkinje do cerebelo. Os axônios destas células, localizados na camada granular, substância branca, medula e pedúnculos cerebelares, sofrem degeneração Walleriana.

\section{Intoxicação por Ipomoea carnea e Sida carpinifolia}

A intoxicação por I. carnea afeta caprinos, ovinos e bovinos na região Nordeste do Brasil. A intoxicação por Sida carpinifolia afeta caprinos, eqüinos e bovinos no sul do Brasil. Clinicamente, estas intoxicações caracterizam-se por sonolência, incoordenação, emagrecimento progressivo, tremores, movimento lateral da cabeça e hipermetria. Estas plantas contém como princípio ativo inibidores enzimáticos que causam enfermidades do armazenamento de oligossacarídeos. Não há lesões macroscópicas significantes. As lesões histológicas caracterizam-se por vacuolização dos neurônios e células de diversos órgãos. No sistema nervoso a vacuo- lização neuronal é difusa, mas mais evidente nas células de Purkinje do cerebelo.

\section{Intoxicação por Halimium brasiliense}

Afeta ovinos no Uruguai e Rio Grande do Sul. Causa convulsões periódicas, que ocorrem principalmente quando os ovinos são movimentados ou assustados. Entre as crises a maioria dos animais não apresenta sinais clínicos; entretanto, alguns apresentam incontinência urinária ou incoordenação dos membros posteriores. Alguns animais, que apresentam crises muito freqüentes, emagrecem progressivamente, caem em decúbito permanente e morrem. Se os ovinos são retirados dos campos onde existe a planta ou depois de novembro, quando o ciclo da planta finaliza, a maioria se recupera. Animais pouco afetados não apresentam lesões histológicas significativas. Naqueles gravemente afetados ocorre degeneração axonal difusa na substância branca, principalmente na medula espinhal e cápsula interna.

\section{Intoxicação por Prosopis juliflora}

A favas desta árvore, quando constituem $50 \%$ ou mais da dieta, e são ingeridas por alguns meses, causam intoxicação em bovinos e caprinos na região Nordeste do Brasil. A intoxicação causa sinais clínicos característicos de insuficiência do trigêmeo: paralisia e atrofia neurogênica do masseter, paralisia mandibular, salivação, língua protusa e mastigação e ruminação com a cara inclinada para que os alimentos não caiam da boca. As lesões histológicas caracterizam-se por degeneração e desaparecimento dos neurônios do núcleo motor do trigêmeo.

\section{Intoxicação por Equisetum spp}

Em eqüinos a intoxicação por Equisetum arvense causa mau desenvolvimento e fraqueza do trem posterior, ataxia e dificuldade de dar a volta. O princípio ativo da planta é uma tiaminase. Lesões no sistema nervoso central não tem sido identificadas. Equisetum palustre afeta bovinos e causa fraqueza progressiva, com sinais de paralisia, precedidos de inquietação ou excitabilidade temporária. Mortes só ocorrem em animais muito doentes que permanecem em decúbito.

\section{Intoxicação por Pteridium aquilinum}

Esta planta contém uma tiaminase capaz de inativar a tiamina, causando em eqüinos sinais clínicos de incoordenação, tremores musculares, ataques convulsivos, opistótono e morte. Não têm sido observadas lesões macroscópicas nem histológicas. No Brasil esta intoxicação foi diagnosticada somente uma vez em asininos.

\section{Diplodiose}

É uma micotoxicose causada por Diplodia maydis, quando são ingeridos os picnídios do fungo que aparecem como pequenos pontos pretos do tamanho da cabeça de um alfinete. Ocorre no Rio Grande do Sul, em restevas de milho. Os sinais clínicos caracterizam-se por lacrimejamento, salivação, tremores musculares, ataxia, paresia e dismetria, com flexão exagerada dos membros durante a marcha. Em alguns animais ocorre paralisia com decúbito permanente seguido de morte. A maioria dos animais recupera-se ao ser retirada das restevas. 
Não se observam lesões macroscópicas nem histológicas significativas.

\section{Leucoencefalomalacia}

É uma enfermidade dos eqüinos causada pela ingestão de milho contaminado com o fungo Fusarium moniliforme. $\mathrm{O}$ desenvolvimento do fungo e suas toxinas (fumonisinas $B_{1}$ e $B_{2}$ ) está intimamente relacionado com a umidade e a ocorrência de quedas de temperatura que causam choque térmico.. Os sinais clínicos caracterizam-se por anorexia, sonolência e depressão ou hiperexcitabilidade, dificuldade de apreensão de alimentos e mastigação, ataxia, tremores, pressão da cabeça contra objetos, torneio, cegueira uni ou bilateral e decúbito. As lesões macroscópicas caracterizam-se por aumento de tamanho de um dos hemisférios cerebrais com amolecimento das circunvoluções. Ao corte a substância branca do cérebro está amarelada, com áreas de malacia, observando-se, geralmente, cavidades contendo fluído. A cápsula interna e o tálamo geralmente estão afetados. Áreas amareladas ou hemorrágicas são raramente observadas nos tubérculos quadrigêmeos, pedúnculos cerebelares, ponte e medula oblonga. As lesões são, geralmente unilaterais e quando bilaterais são mais marcadas em um dos lados do encéfalo.

\section{Babesiose}

A babesiose causada por Babesia bovis causa agressividade ou depressão, prostração, febre e ataques convulsivos. Raramente observa-se hemoglobinúria nesta forma da enfermidade. Macroscopicamente, aparece severa congestão do córtex cerebral. Em esfregaços e cortes histológicos do córtex cerebral, e em menor quantidade em outros órgãos, observam-se numerosas $B$. bovis em eritrócitos que se encontram marginando as paredes dos capilares. Outras lesões macroscópicas são as hemorragias pericárdicas, o aumento de tamanho do baço e a icterícia com fígado amarelo ou alaranjado.

\section{Mieloencefalite equiina por protozoário}

É uma enfermidade neurológica infecciosa de eqüinos, geralmente fatal, transmitida pelo agente protozoário Sarcocystis neurona. Os sinais clínicos são variáveis e dependem da região e da extensão das lesões, as quais são multifocais. Observam-se malacia e reação inflamatória não supurativa. As lesões afetam mais freqüentemente a medula e a apresentação mais comum é uma alteração na marcha, com o comprometimento de um ou mais membros, dependendo da localização das lesões na medula. Usualmente, há ataxia assimétrica dos membros posteriores, fraqueza e atrofia musculares. Quando está envolvido o tronco encefálico e os núcleos dos nervos cranianos observa-se depressão, ataxia, paralisia facial e protusão, flacidez e paralisia da língua, atrofia dos músculos temporal e masseter e disfagia. Quando a lesão é no cérebro pode observar-se depressão, alterações no comportamento, cegueira e diminuição das respostas sensoriais à ameaça no lado da face contralateral à lesão.

\section{Intoxicação por organofosforados e carbamatos}

Causa salivação, miose, bradicardia, diarréia, tremores musculares, tetania, ataxia, desorientação, convulsões e coma.
Nos casos crônicos observam-se lesões histológicas de degeneração dos nervos periféricos e tratos da medula espinhal.

\section{Cetose}

É uma enfermidade metabólica que afeta bovinos de alta produção e ovinos com prenhez múltipla. No Rio Grande do Sul e no Uruguai tem sido descrita, também, em vacas prenhes gordas (principalmente novilhas e vacas falhadas do ano anterior), que sofrem restrição alimentar no último mês de gestação. Em ovinos e vacas prenhes predominam os sinais nervosos. As ovelhas separam-se do rebanho e parecem cegas, permanecendo alerta mas sem movimentar-se. Se são forçadas a andar batem em objetos ou pressionam a cabeça contra os mesmos. Posteriormente, apresentam tremores musculares e convulsões. Morrem em depressão profunda depois de 2 a 7 dias. Nas vacas prenhes observam-se hiperexcitabilidade, agressividade, atitude de alerta, tremores musculares e incoordenação; 1 a 4 dias depois dos primeiros sinais nervosos ocorre decúbito permanente e posteriormente morte. Em bovinos, ao contrário dos ovinos, o tratamento antes do decúbito é eficiente. Os sinais nervosos ocorrem por hipoglicemia e não há lesões macroscópicas nem histológicas no SN. Observa-se degeneração gordurosa do fígado.

\section{Hipocalcemia}

É uma enfermidade metabólica que afeta vacas no período perinatal, principalmente nas primeiras 48 horas depois do parto. Inicialmente, observam-se excitação e hiperexcitabilidade com tremores musculares, movimentos de cabeça, mugidos e dispnéia. Estes sinais evoluem para o decúbito esternal, com diminuição dos reflexos, midríase, decúbito lateral, perda da consciência e coma. A maioria dos animais se recupera depois do tratamento com cálcio.

Para maiores informações sobre as doenças mencionadas consultar Tokarnia et al. (2000) e Riet-Correa et al. (2001).

\section{REFERENCIAS}

De Lahunta A. 1983. Veterinary Neuroanatomy and Clinical Neurology. $2^{\text {nd }}$ ed. V.W. Saunders, Philadelphia. 271p.

King A.S. 1994. Physiological and Clinical Anatomy of the Domestic Mammals. Central Nervous System. Oxford University Press, Oxford. 325p.

Loretti A.P., Colodel E.M., Driemeier D., Corrêa A.M., Bangel Júnior J.J., Ferreiro L. 2003. Neurological disorder in dairy cattle associated with the consumption of beer residues contaminated with Aspergillus clavatus. J.Vet. Diag. Invest. (Em publicação)

Mayhew I. G. 1989. Large Animal Neurology. Lea \& Febiger, Philadelphia. 380p.

Merck Veterinary Manual 2001. $8^{\text {th }}$ edition. Aiello S.E. (ed.), Merck \& Co, USA, p. 889-896.

Radostits E.M., Gay C.C., Blood D.C. \& Hinchcliff K.W. 2000. Veterinary Medicine. $9^{\text {th }}$ edition. W.B. Saunders, London, p. 501-550.

Riet-Correa F., Schild A.L., Mendez M.C. \& Lemos R.A.A. 2001. Doenças de Ruminantes e Eqüinos. $2^{a}$ ed. Varela, São Paulo. Vol 1, 425p., Vol 2 , 573 p.

Summers B.A., Cummings J.F. \& De Lahunta A. 1995. Veterinary Neuropathology. Ed. Mosby, St Louis. 527 p.

Tokarnia C.H., Döbereiner J. \& Peixoto P.V. 2000. Plantas Tóxicas do Brasil. Editora Helianthus, Rio de Janeiro. 310p. 